\title{
Ironi, humor og opgøret med Hegel i Efterskriften
}

\section{Ph.d.-stipendiat, mag.art. Mads Gram Henriksen}

Abstract: During the last decades, literary studies have shed a long awaited light on the complexities and specificities of Kierkegaard's writing style. Possibly due to their focus on his so-called aesthetic works, they have left the impression that his style generally is motivated by aesthetic reasons. Contrary to this impression, I argue that Kierkegaard's style is intrinsically related to the overall project in his authorship, i.e. to become a Christian. In the Postscript, Climacus' account of what it means to become a Christian is presented largely as a criticism of Hegel's philosophy and Hegelian theology. In the article, I explore the significance of style for Climacus' account and I discuss the difference between irony and humour as forms of communication and their inherent limitations. Furthermore, I argue for a connection between irony and humour in the Postscript and what Kierkegaard called "ethical" and "ethical-religious" forms of communication in his unpublished manuscripts.

Key words: Kierkegaard - Irony - Humour - Hegel - Christianity.

Den, der antager, at Philosophien aldrig i Verden har været saa nær ved at løse sin Opgave: at forklare alle Gaader, som nu, ham kan det vel forekomme besynderligt, søgt, forargeligt, at jeg vælger Fortællingens Form, og ikke efter fattig Leilighed langer Steen med til at sætte Toppen på Systemet. Den derimod, der har forvisset sig om, at Philosophien aldrig har været saa forskruet som nu, saa forvirret trods alle sine Bestemmelser, [...] han vil visselig finde det i sin Orden, at jeg ogsaa ved Formen søger at modarbeide den vederstyggelige Usandhed, der er den nyere Philosophies Kjendetegn. ${ }^{1}$

Passagen findes i teksten Johannes Climacus eller De omnibus dubitandum est, som Kierkegaard affattede omkring 1842-43, men ikke selv publicerede. Her foregribes en række af de temaer, som bliver tone-

1. Søren Kierkegaard, Søren Kierkegaards Papirer. Bind IV Søren Kierkegaards Optegnelser fra 1842 20. November til 1844 Marts (København: Gyldendal 1968), B 1. 
angivende i forfatterskabet. Udgangspunktet er en kritik af antagelsen om, at filosofien skal "forklare alle Gaader". Kritikken sigter først og fremmest på Hegel og hans tilhængere. Dette fremstår desto tydeligere, når der efterfølgende refereres til forsøget på at sætte "Toppen på Systemet”, dvs. til højre-hegelianernes forsøg på at genplacere kristendommen i det filosofiske system som systemets top. Inden for en dansk kontekst var det især Martensen, der i sin udformning af en spekulativ teologi byggede videre på Hegels filosofiske system. ${ }^{2}$ Martensen hævdede, at tro og viden kan forenes (Martensen 1850, 14), dvs. at kristendommen kan forklares, at Kristus ikke er et paradoks og at den højeste viden ikke er en gåde (Martensen 1850, 17-21). I hegelianernes spekulative teologi udfoldes den tanke, som Kierkegaard finder indlejret i Hegels systematiske filosofi: at alt kan forklares. De kritiske bemærkninger i passagen angår filosofien, hvor den forsøger at forklare troen. I modsætning til f.eks. Martensen forsvarer Kierkegaard det synspunkt, at Kristus er et paradoks for fornuften og at tro i den forstand er tro mod fornuften. Når hegelianerne insisterer på at forholde sig forklarende til det, som ifølge Kierkegaard ikke kan forklares, bliver deres forklaring til en bortforklaring, ${ }^{3}$ dvs. den afstedkommer en bortskaffelse af det "forklarede" - i dette tilfælde troen. Passagen ovenfor lader os ikke blot ane, at Kierkegaard vil "modarbeide" den systematiske filosofi. Den fortæller også noget om, hvordan han vil gøre det, nemlig "ved Formen".

Det er næppe en underdrivelse at hævde, at Kierkegaards stil ikke har været genstand for meget opmærksomhed i Kierkegaard-receptionen, der hovedsageligt har udspillet sig inden for en teologisk og filosofisk kontekst. Der findes dog undtagelser. ${ }^{4}$ Lidt forenklet kan man sige, at hvor teologer og filosoffer traditionelt har læst Kierkegaards tekster tematisk, så har litterater og retorikere især de seneste årtier læst dem stilistisk. ${ }^{5}$ For de førstnævnte gælder det også de steder i forfatterskabet, hvor stilen netop er temaet - f.eks. Climacus' fremstil-

2. Hans L. Martensen, Dogmatiske Oplysninger, et Lejlighedsskrift (København: C.A. Reitzel 1850).

3. Søren Kierkegaard, Søren Kierkegaards Skrifter. Bind 7 Afsluttende uvidenskabelig Efterskrift (København: Gads Forlag 2002), 281.

4. F.eks. Paul Müller, Meddelelsesdialektikken i Søren Kierkegaards Philosophiske Smuler (København: C.A. Reitzel 1979), Paul Müller, Søren Kierkegaards kommunikationsteori (København: C.A. Reitzel 1984), Tim Hagemann, Reden und Existieren. Kierkegaards antipersuasive Rhetorik (Berlin: PHILO 2001), og John Lippitt, Humour and irony in Kierkegaard's thought (London: Macmillan 2000).

5. F.eks. Joakim Garff, "Den Søvnløse". Kierkegaard last astetisk/biografisk (København: C.A. Reitzel 1995), Isak Winkel Holm, Tanken i billedet. Søren Kierkegaards poetik (København: Gyldendal 1998), og Jacob Bøggild, Ironiens tenker - tenkningens ironi : Kierkegaard lest retorisk (København: Museum Tusculanum 2002). 
ling af den indirekte meddelelsesteori i Afsluttende uvidenskabelig Efterskrift (SKS 7, 73-80). Om den indirekte meddelelse hævder Løgstrup, at den "er uholdbar", for dens formål er "at stille det andet menneske frit", men "det modsatte sker". ${ }^{6}$ Grøn fremsætter en lignende kritik i sin disputats: den indirekte meddelelse vil anerkende, at den anden er et selvforhold og dens sigte er at sætte modtageren fri til egen stillingtagen, men for at opnå dette går meddeleren bag om modtagerens selvforhold og bedrager ham ind i sandheden. ${ }^{7}$ Den indirekte meddelelsesteori synes altså at forråde sit eget formål: at anerkende modtagerens selvforhold (Grøn 1997, 151). Jeg er for så vidt ikke uenig i denne kritik, men jeg mener dog ikke, at den indirekte meddelelsesteori bør lades ude af betragtning, fordi den rummer indre spændinger. I så fald bør vi ikke blot se bort fra fremstillingen af meddelelsesteorien i Efterskriften, men også fra store dele af det øvrige pseudonyme forfatterskab, der ifølge Kierkegaard netop udspiller sig på den indirekte meddelelses præmisser $(S K S 7,570)$.

De stilistiske læsninger har selvsagt fokuseret på stilen, men ofte er dette fokus begrænset til kun at omfatte Kierkegaards såkaldte æstetiske skrifter, hvormed hans teologiske og filosofiske motiver træder i baggrunden eller helt forsvinder. Jeg er enig med Winkel Holm, når han hævder, at negativiteten ved den indirekte meddelelse ikke blot består $i$, at meddeleren ifører sit budskab en drillende form, men snarere $\mathrm{i}$ at formen yder modstand mod forståelsesforsøg og at det er denne modstand, der skal fremkalde modtagerens selvstændige stillingtagen (Winkel Holm 1998, 310ff.). Men Winkel Holm hævder endvidere, at den indirekte meddelelsesteori udvikles på baggrund af refleksioner over æstetisk negativitet: "For at kunne forstå Efterskriftens sært skødesløse teori om "Meddelelsens Negativitet" er man nødt til at tolke den på baggrund af det tidlige forfatterskabs undersøgelse af problemet æstetisk negativitet” (ibid., 313). Man kan her få det indtryk, at Kierkegaards stilistiske strategier primært har litterære ambitioner eller at spørgsmålet om stilen udspringer af æstetiske overvejelser. Dette mener jeg ikke er tilfældet og det er i den forstand, jeg hævder, at Kierkegaards projekt har tendens til at fortone sig i de stilistiske læsninger. I Om min Forfatter-Virksombed sætter han sit projekt på formel: "hele Forfatterskabets Problem: 'det at blive Christen"”. 8

6. K.E. Løgstrup, Opgør med Kierkegaard (København: Gyldendal 1994), 147.

7. Arne Grøn, Subjektivitet og negativitet (København: Gyldendal 1997), 249-252.

8. Søren Kierkegaard, Søren Kierkegaards Skrifter. Bind 13 Om min Forfatter-Virksombed. Til Selvprøvelse Samtiden anbefalet. Dette skal siges; saa vare det da sagt. Hvad Christus dommer om officiel Christendom . Guds Uforanderlighed • Oieblikket nr. 1-10 (2009) (København: Gads Forlag 2002), 14. 
Jeg fremsætter i teksten det argument, at Kierkegaards stilistiske strategier er motiveret af filosofiske og teologiske grunde snarere end af litterære og æstetiske. Mere præcist rejser teksten spørgsmålet om stilens betydning for Kierkegaards opgør med Hegels filosofi og dermed hegelianernes spekulative teologi. I stedet for at vælge en stilistisk læsning frem for en tematisk læsning vil jeg prøve at komme til det tematiske gennem det stilistiske.

\section{Hemmelighederne i Enten-Eller}

"Det er maaskee dog stundom faldet Dig ind, kjære Læser, at tvivle en Smule om Rigtigheden af den bekjendte philosophiske Sætning, at det Udvortes er det Indvortes, det Indvortes det Udvortes". 9 Sådan åbner Victor Eremita Enten - Eller. For at forstå hvad der er på spil i denne sætning må vi først prøve at se, hvad begreberne betyder i den kontekst, som han refererer til. Den "bekjendte philosophiske Sætning", som han tvivler om rigtigheden af, er en central formulering fra Hegels logik. ${ }^{10}$ I den del af logikken, der omhandler begrebet væsen og overgangen fra begrebet væren til begrebet væsen, udledes de såkaldte par af refleksionsbegreber. Blandt refleksionsbegreberne er det Indvortes (det indre) og det Udvortes (det ydre). Ifølge Hegel ligger modsigelsen, som refleksionsbegreberne fremstiller, ikke i disse begreber, men i stedet i begrebet væsen. Derfor kan han hævde, at modsigelsen kan ophæves $i$ en enhed af det indre og det ydre. Han tænker denne enhed som identifikationen af det indre og det ydre, og han bestemmer denne enhed som virkeligheden (ibid. \$142). Ifølge Hegel er erkendelse af virkeligheden ikke erkendelse ved forstanden, men erkendelse ved fornuften. Fornuften fornemmer væsenet og væsenet er fornuften selv. Derfor kan han hævde, at det fornuftige og det virkelige er ét. ${ }^{11}$ Den spekulative logik udgør således ikke blot indledningen til men mere afgørende grundlaget for det filosofiske system. Når Eremita tvivler om rigtigheden af den "bekjendte philosophiske Sætning”, tvivler han på systemets grundlag.

I Hegels filosofi er det indre og det ydre abstrakte begreber. Eremitas næste sætning afslører, at han anvender begreberne på en anderledes, konkret måde: "Du har maaskee selv gjemt en Hemmelighed, om hvilken Du følte, at den, i sin Glæde eller i sin Smerte, var Dig for kjær til, at Du kunde indvie Andre i den" (SKS 2, 11). I Eremitas

9. Søren Kierkegaard, Søren Kierkegaards Skrifter. Bind 2 Enten - Eller, Første del (København: Gads Forlag 1997), 11.

10. Enzyklopädie der philosophischen Wissenschaften im Grundrisse, \$139.

11. Grundlinien der Philosophie des Rechts, xix. 
tekst henviser det indre altså til hemmeligheden. En hemmelighed skal her ikke forstås i begrebets almindelige betydning, hvor det betyder sådan noget som at tilbageholde noget fra nogen. Når begrebet forstås sådan, bliver en hemmelighed ensbetydende med noget, der ikke meddeles, men som principielt kan meddeles direkte. Men ifølge Eremita kan en hemmelighed hverken meddeles direkte eller forstås ligefremt og deri ligger dens betydning. Hos Eremita står det indre i modsætning til det ydre, der her skal forstås som det, der kan meddeles direkte og forstås ligefremt. De forskellige forfattere i Enten - Eller viser nu på skift, at hverken det æstetiske (1. del), det etiske (2. del) eller det religiøse (ultimatum) kan meddeles direkte. I Enten - Eller udgør både det æstetiske, det etiske og det religiøse altså en hemmelighed. Det indikeres allerede i forordet og især i beretningen om hvordan Eremita kom i besiddelse af papirerne, som han senere udgiver under overskriften Enten - Eller. Det er selvfølgelig ikke tilfældigt, at han netop finder papirerne gemt $\mathrm{i}$ en sekretær, dvs. $\mathrm{i}$ et møbel, der er konstrueret sådan, at når overdelens skriveklap lukkes, skjules flere mindre rum. Den etymologiske betydning af sekreter er 'hemmeligt sted' (fr. secrétaire, fra lat. secretarium) eller blot 'hemmelighed' (lat. secretum). Scenen er dermed sat og opgaven er at formidle de fundne hemmeligheder. Ligesom det fordrede anstrengelse før det lykkedes Eremita at tvinge sig adgang til det hemmelige rum, må læseren af forordet forberede sig på, at ingen af de hemmeligheder, der efterfølgende meddeles, lader sig begribe på nogen enkel eller ligefrem måde. For når det gælder hemmeligheder af denne type, så står det indre i modsætning til det ydre.

Fra de første linjer i Enten - Eller kan vi se, at Eremita gør retorisk brug af begreber, som i Hegels filosofi betyder noget andet. Kierkegaards opgør med den spekulative filosofi begynder med en stilistisk forskydning af Hegels begreber. Der er allerede fra forfatterskabets begyndelse stilistiske strategier, skønt der endnu ikke foreligger en udarbejdet meddelelsesteori.

\section{Eksistensen som problem:} optakt til den indirekte meddelelsesteori

Den negativitet, der karakteriserer den indirekte meddelelse, afspejler eksistensens negativitet. Har man først erfaret dette grundvilkår, så er opgaven for den der vil formidle et eksistentielt budskab at finde en udtryksform, der medtænker denne negativitet frem for at fortrænge den. For bedre at forstå, hvad Winkel Holm kaldte den "sært skødesløse teori om meddelelsens negativitet”, vil jeg først vise, at den indi- 
rekte meddelelsesteori udvikles som et led i opgøret med Hegel, før jeg diskuterer meddelelsesteorien. I den forbindelse skitseres Climacus' opfattelse af eksistensen og de problemer, han mener, den blotlægger ved Hegels filosofi. At Climacus utvivlsomt tegner et karikeret billede af såvel Hegel som den danske hegelianisme og at disse sagtens kan forsvares mod denne kritik er ikke relevant for vores forehavende. ${ }^{12}$

I Efterskriften kritiserer Climacus Hegels filosofi ved at pege på eksistensen som et fænomen, der ikke kan indfanges i systemet (SKS 7, 285f.). Eremitas tvivl og Climacus' kritik retter sig mod samme del af Hegels logik men på forskellie niveauer. Hvor Eremita anfægter rigtigheden af Hegels påstand, at "det Udvortes er det Indvortes, det Indvortes det Udvortes", stiller Climacus ikke blot spørgsmål ved muligheden for en overgang fra forstandserkendelse (abstrakt tænkning) til fornuftserkendelse (den rene tænken) - han hævder, at den rene tænken er "et Phantom" (SKS 7, 286). Hvor forstanden tænker det almene ved at abstrahere fra det enkelte, abstraherer fornuften fra forstandens abstraktion. Den rene tænken er ifølge Climacus uden noget forhold til eksistensen, som derfor ikke kan indfanges i det filosofiske system.

Men hvordan forstår Climacus eksistens og hvorfor kan den ikke tænkes? I Efterskriften bestemmer han eksistensen på følgende måde: "Det er hiint Barn, som er avlet af det Uendelige og det Endelige, det Evige og det Timelige, og derfor er bestandigt stræbende" (SKS 7, 91). Denne bestemmelse er en litterær variation af Sokrates' beskrivelse af Eros (Symposion, 202d). Climacus bestemmer altså eksistensen som en syntese af modsætninger og han definerer mennesket som et "Mellemvæsen" (SKS 7, 301), som er sammensat af det uendelige (ånd) og det endelige (sanselighed). Denne syntese er ikke sat én gang for alle, men må til stadighed tilvejebringes. Mennesket er stillet foran den opgave at forene disse modsætninger i sin eksistens. De såkaldte eksistenssfærer afspejler forskellige former for levevis, der udspringer af de mulige måder, hvorpå mennesket ifølge Kierkegaard kan forvalte denne opgave. Climacus' bestemmelse af eksistensen står

12. Den traditionelle udlægning af Kierkegaard som anti-hegelianer findes bl.a. i Niels Thulstrup, Kierkegaards forhold til Hegel og til den spekulative idealisme indtil 1846 (København: Gyldendal 1967). For en kritik af denne udlægning samt en revurdering af Kierkegaards forhold til Hegel, se f.eks. Jon Stewart, Kierkegaard's Relations to Hegel Reconsidered (Cambridge: Cambridge University Press 2003), og Jon Stewart, "Hegel: Kierkegaard's Reading and Use of Hegel's Primary Texts", Kierkegaard and His German Contemporaries, Kierkegaard Research: Sources, Reception, and Resources. Vol. 6: Tome 1, red. Jon Stewart (Aldershot: Ashgate 2007), 97-164. 
i kontrast til Hegels abstrakte fremstilling af eksistensbegrebet som en væsenskategori i den anden bog i Wissenschaft der Logik. Hegel indleder sin logik med de mest abstrakte begreber (værenskategorierne i den første bog) og udvikler derfra sine begreber i en dialektisk bevægelse frem mod en stadig højere grad af konkretion. Men ifølge Climacus kan eksistensen, der altid er konkret og individuel, ikke tænkes abstrakt uden dermed at reducere den til noget, den ikke er: "at existere betyder først og fremmest at være en Enkelt, og derfor er det, at Tænkningen maa see bort fra Existents, fordi det Enkelte ikke lader sig tænke, men kun det Almene" (SKS 7, 298). Såfremt det alligevel skal lykkes at tænke eksistensen, så er opgaven og dermed vanskeligheden at tænke det almene og det enkelte sammen, at tænke det abstrakte konkret $(S K S 7,322)$. Han anklager Hegel for at se bort fra denne vanskelighed - og alligevel "bryster [Hegel] sig af at forklare Alt" (SKS 7, 275). Ifølge Climacus forklarer Hegel ikke eksistensen han bortforklarer den. Climacus stiller derfor spørgsmål ved Hegels forklaring: "At forklare Noget, er det at ophave det?" (SKS 7, 202). Spørgsmålet peger tilbage til indvendingerne mod det filosofiske system, hvilket fremgår desto tydeligere, når Climacus efterfølgende anvender det tyske verbum aufheben.

"Ak, medens den speculerende velbaarne Hr. Professor forklarer hele Tilværelsen, har han i Distraction glemt, hvad han selv hedder: at han er et Menneske, et slet og ret Menneske, ikke en phantastisk $3 / 8$ af en $\$ ”(S K S 7,135)$. I forelæsningsudkastene generaliserer Kierkegaard sin kritik af Hegel: "Man har glemt hvad det er at være Menneske". ${ }^{13}$ Et første skridt i retning af en overvindelse af den eksistentielle glemsel består derfor i at stille spørgsmålet igen: Hvad vil det sige at være et enkelt, eksisterende menneske? Forsøget på at besvare dette spørgsmål tegner konturerne af Kierkegaards projekt: "Er det Tidens Ulykke, at have glemt hvad Inderlighed er og det at existere, gjelder det jo især om at komme Existentsen saa nær som muligt" $(S K S 7,263)$. Han tager den vanskelighed op, som han kritiserer Hegel for at udelade og tesen er, at såfremt tænkningen skal komme eksistensen nær, så må den tænkendes "Tanke svare til Existentsens Form” (SKS 7, 80).

13. Søren Kierkegaard, Søren Kierkegaards Papirer. Bind VIII 2 Søren Kierkegaards Optegnelser fra 1847 24. Januar til 1848 15. Maj. Gruppe B og C København: Gyldendal 1968), B 82,9. 


\section{Den subjektive tænker og den indirekte meddelelsesteori}

Climacus skelner mellem to former for refleksion: den refleksion der kendetegner den objektive tænkning og den refleksion der kendetegner den subjektive tænker (SKS 7, 73). Forskellen mellem de to refleksionsformer udtrykkes i meddelelsesformen. Refleksionen, der kendetegner den objektive tænkning, angår alene tankens indhold. Den objektive tænknings meddelelsesform er derfor direkte. En direkte meddelelse er en meddelelse af viden. En sådan meddelelse er ikke nødvendigvis let at forstå, men "den lader sig ligefrem forstaa, den lader sig ramse" (SKS 7, 76). Det afgørende i et direkte meddelelsesforløb er meddelelsens indhold. Det er kun tanken og ikke tænkeren der her er væsentlig. Formentlig i kraft af denne eksistentielle anonymitet skriver Climacus gerne "den objektive Tænkning". Anderledes forholder det sig med den subjektive tænkers refleksion og meddelelsesform. Climacus skriver, at den subjektive tænkers refleksion er dobbelt: "Tænkende tænker han det Almene, men som existerende i denne Tænkning, som erhvervende denne i sin Inderlighed bliver han mere og mere subjektivt isoleret" (SKS 7, 74). Tankens indhold er det almene, men gennem dobbelt-refleksionen sætter den subjektive tænker sin tænkning i eksistens, så han eksisterer i det tænkte (Müller 1984, 39). Dobbelt-refleksionen fører således tanken (det almene) tilbage på eksistensen (det enkelte). Den subjektive tænker kommer eksistensen nær, fordi han i sin tænkning medtænker sin eksistens.

Climacus betoner flere steder, at den subjektive tænker ikke kan meddele sit budskab på nogen direkte måde (SKS 7, 74f.). Kierkegaard beskriver andetsteds forskellen mellem det direkte og det indirekte meddelelsesforløb på følgende måde (SKS 13, 14): i førstnævnte situation er modtageren at sammenligne med "det tomme Kar der skal fyldes"; i sidstnævnte situation er formålet ikke at tilføre modtageren mere viden, men snarere at fratage ham selvfølgeligheden ved den viden, han allerede har, og dermed muliggøre at han kan tilegne sig meddelelsen. Udgangspunktet for den indirekte meddelelsesteori er både en anerkendelse af modtagerens selvforhold og en antagelse om, at en eksistentiel meddelelse kun kan modtages som sådan, hvis den tilegnes. Det indirekte meddelelsesforløb handler derfor hverken om meddeleren eller om meddelelsens indhold, men om hvad der for modtageren er på spil i meddelelsen. Formålet med meddelelsen er at hjælpe den anden til bedre at forstå sig selv i eksistens. Der er selvsagt ingen garanti for at dette lykkes, men tesen er at såfremt det skal lykkes, må meddeleren skubbe modtageren fra sig, så han stilles fri til selv-afgørelse. Den indirekte meddelelsesform ligner således den so- 
kratiske meddelelsesform. Det er derfor ikke tilfældigt, at Climacus i begyndelsen af Philosophiske Smuler diskuterer Sokrates' maieutik, ${ }^{14}$ og at han i Efterskriften gentagne gange refererer til Sokrates som en subjektiv tænker, der mestrede den indirekte meddelelseskunst (SKS 7, 80). I forelæsningsudkastene beskriver Kierkegaard det maieutiske forhold med formlen: "At staae ene - ved en Andens Hjælp" (Pap. VIII 2 B 82,15). Formlen er med Kierkegaards ord "en Formel for Ironi", for "At staae ene, er jo ikke at staae ved en Andens Hjælp". Kierkegaard benytter som bekendt ikke kun ironibegrebet i dets hverdagslige betydning, hvor det betyder sådan noget som at udtrykke noget man ikke mener, men på en måde så det alligevel fremgår hvad man mener. Hos ham betyder begrebet snarere en brydning af modsætninger, hvori noget kommer til syne. I indledningen til sin afhandling Om Begrebet Ironi reflekterer han over de metodiske vanskeligheder, der er forbundet med at lade ironien (som Sokrates her personificerer) fremtræde og han hævder, at det er ligeså besværligt at fastholde et billede af Sokrates, som det er "at afbilde en Nisse med den Hat, der gjør ham usynlig". ${ }^{15}$ Her bestemmer han - via Sokrates - ironi som modsætningsforholdet mellem det indre og det ydre (SKS 1, 74). Lippitt hævder, at denne bestemmelse af ironibegrebet ikke blot består i, at udtrykkets mening skal forstås som det modsatte af det sagte (Lippitt 2000, 137ff.). Lippitt inddrager her Vlastos' redegørelse for forholdet mellem simpel og kompleks ironi, ${ }^{16}$ og Lippitt peger på, at selv når vi har erfaret, at Sokrates' indre ikke stemmer overens med hans ydre fremtrædelse, så har vi stadigvæk ikke adgang til hans indre (Lippitt 2000, 138). Ifølge Lippitt rummer Kierkegaards ironibegreb ikke kun den betydning, at meningen er det modsatte af det sagte (simpel ironi), men også den betydning at meningen er noget ubestemt andet end det sagte (kompleks ironi). Med den ubestemte mening bliver ironien gådefuld. Ligesom det er tilfældet med den sokratiske maieutik, efterlader den indirekte meddelelse modtageren med en gåde, som hun selv må løse. Det er med denne komplekse betydning af ironibegrebet in mente, at jeg bestemmer den indirekte meddelelsesform som ironi. Ironi medfører altså ikke, at meddelelsen ikke er alvorlig. Snarere tværtimod; tesen er jo, at ethvert eksistentielt budskab fordrer en indirekte meddelelsesform. Det

14. Søren Kierkegaard, Søren Kierkegaards Skrifter. Bind 4 Gjentagelsen · Frygt og Baven - Philosophiske Smuler · Begrebet Angest - Forord (København: Gads Forlag 1997), 219f. For en studie heraf, se f.eks. Müller (1979).

15. Søren Kierkegaard, Søren Kierkegaards Skrifter. Bind 1 Af en endnu levendes Papirer. Om Begrebet Ironi (København: Gads Forlag 1997), 74.

16. Gregory Vlastos, Socrates: Ironist and Moral Philosopher (Cambridge: Cambridge University Press 1991). 
fremgik allerede af Enten - Eller, hvor såvel den æstetiske, den etiske som den religiøse forfatter meddelte sig indirekte. Selvom Climacus er det forfatterpseudonym, der fremstiller den indirekte meddelelsesteori, så vil jeg nu vise, at hans stil ikke kan reduceres til ironi. Nogle overvejelser over hans projekt kan lede os på rette vej.

\section{Climacus' tanke-projekt}

I Efterskriftens tillæg "Forstaaelsen med Læseren" findes Climacus' berygtede tilbagekaldelse: "saaledes indeholder hvad jeg skriver tillige en Efterretning om, at Alt skal forstaaes saaledes, at det er tilbagekaldt; at Bogen ikke blot har en Slutning, men ovenikjøbet en Tilbagekaldelse" (SKS 7, 562). Det er dog ikke entydigt, hvordan tilbagekaldelsen skal forstås - endsige hvad Climacus nærmere bestemt tilbagekalder. Ifølge Conant er formålet med tilbagekaldelsen at vise, at det at blive kristen ikke er et epistemologisk spørgsmål, dvs. at det ikke er et spørgsmål, der kan afgøres ved at søge mere viden. ${ }^{17}$ Han hævder, at Climacus, der kritiserer filosofferne for at konstruere den kristne tro som en form for viden, selv fremsætter en antitese (at viden og tro ikke kan forenes) mod hegelianernes tese (at viden og tro kan forenes), og at denne antitese farr karakter af en filosofisk doktrin om kristendommen (Conant 1993, 213). I den forstand synes Climacus at begå den samme fejl, som han kritiserer især hegelianerne for at begå, nemlig at sammenblande filosofi og kristendom. Conants pointe er dog snarere, at Climacus parodierer de filosofiske bestræbelser på at forklare, hvad det vil sige at være kristen (ibid., 207), og idet han udvikler sine argumenter til deres grænse, demonstrerer han, at også hans egen position ender i nonsens (ibid., 215). Conant hævder altså både at projektet i Efterskriften udgør en omfattende reductio ad absurdum af filosoffernes forsøg på at forklare troen (ibid., 207) og at Efterskriften til sidst viser sig som meningsløs (ibid., 215f.), dvs. såfremt man har forstået bogen, forstår man tillige, at dens indhold er nonsens.

17. Se f.eks. James Conant, "Must We Show What We Cannot Say?", The Senses of Stanley Cavell, red. Richard Fleming \& Michael Payne (Lewisburg, PA: Bucknell University Press 1989), 242-283; James Conant, "Kierkegaard, Wittgenstein, and Nonsense", Pursuits of Reason: Essays in Honor of Stanley Cavell, red. Ted Cohen, Paul Guyer \& Hilary Putnam (Lubbock, TX: Texas Tech University Press 1993), 195-224; James Conant, "Putting Two and Two Together: Kierkegaard, Wittgenstein, and the Point of View for Their Work as Authors", Philosophy and the Grammar of Religious Belief, Claremont Studies in the Philosophy of Religion, red. Timothy Tessin \& Mario von der Ruhr (Basingstoke: Macmillan 1995), 248-331. 
Denne udlægning af tilbagekaldelsen er blevet kritiseret af blandt andre Lippitt. ${ }^{18}$ Han hævder, at hvis vi tager højde for, at Climacus definerer sig selv som humorist, så forekommer Conants udlægning, der så at sige tager Climacus' tilbagekaldelse bogstaveligt, problematisk; "we should not expect 'humorists' - as Climacus describes them - to be so authoritarian" (Lippitt 1997, 192). Det er en rimelig indvending, ikke mindst fordi Climacus få linier før tilbagekaldelsen selv skriver: "At være Autoritet er altfor byrdefuld en Existents for en $\mathrm{Hu}$ morist" (SKS 7, 561). Men hvis tilbagekaldelsen ikke skal læses som en autoritativ instruktion til læseren om at smide bogen væk, hvordan skal den så læses? På baggrund af en redegørelse for humoristens karaktertræk, som Lippitt identificerer som henholdsvis beskedenhed (modesty) og manglende sans for vigtighed eller påtrængende nødvendighed (lack of sense of urgency) (1997, 192; 2000, 60), foreslår han at læse tilbagekaldelsen som et udtryk for beskedenhed (1997, 191). Denne beskedenhed skal ifølge Lippitt forstås som benægtelse af autoritet, hvilket han fremhæver som en væsentlig del af den maieutiske metode $(2000,59)$. Lippitt mener bl.a. at finde belæg for sin udlægning i en passage, hvor Climacus præciserer "at det at skrive en Bog og tilbagekalde den er noget Andet end at lade være at skrive den, at det at skrive en Bog, som ikke fordrer Betydning for Nogen, dog er noget Andet, end at lade den uskreven" (Lippitt 1997, 191; $S K S$ 7, 563). Jeg mener, at Lippitt er på rette spor i sin udlægning af tilbagekaldelsen som en indirekte meddelelse, men også at hans bestemmelse af Climacus' stil, humoren, som en indirekte meddelelse ikke er tilstrækkelig præcis (Lippitt 2000, 161). Lad os derfor prøve at opspore forskellen mellem ironi og humor.

Som nævnt definerer Climacus sig selv som humorist og han betoner i den forbindelse, at han hverken er kristen eller har været kristen for "han er jo fuldt op beskjæftiget med, hvor vanskeligt det maa være at blive det" $(S K S$ 7, 560). Climacus' projekt er at beskrive den proces det er at blive kristen. Hans opgave er ikke at meddele en kristen sandhed, som han allerede er i besiddelse af, men at nærme sig sandheden, at erfare og meddele den proces, der fører frem til sandheden. Det fremgår desuden, når han kritiserer samtidens opfattelse af forholdet mellem humor og kristendom, der gør "Humor til det Høieste indenfor Christendom" (SKS 7, 547), hvortil Climacus hævder, at humoren aldrig har "Ret i at erklære sig for Christendom" (SKS 7, 245). Som det også fremgår af kommentarbindet til Efter-

18. John Lippitt, "A Funny Thing Happened to Me on the Way to Salvation: Climacus as Humourist in Kierkegaard's Concluding Unscientific Postscripts", Religious Studies 33:2 (1997), 181-202. 
skriften, så retter Climacus' kritik sig her mod hegelianernes og især Martensens opfattelse af humoren som "den højeste, kristelige livsanskuelse"; 19 f.eks. hævder Martensen, at "Det Humoristiske er den inderste Baggrund i al christelig Verdensbetragtning". ${ }^{20}$ Climacus distancerer sig fra Martensens objektive humor og fremstiller i stedet en eksisterende subjektiv humorist, ${ }^{21}$ der netop ikke er kristen, men som er optaget af, hvad det vil sige at blive kristen. I en passage, der omhandler forfatterskabets motiv, beskriver Climacus hvorledes "de sande Tidens Velgjørere" gavner menneskeheden "ved at gjøre Aands-Existentsen i Kraft af Tanke systematisk lettere og lettere og dog betydningsfuldere og betydningsfuldere", og han bestemmer sit projekt i forhold til dem: "da det for Dine indskrænkede Evner vil være umuligt at gjøre Noget lettere end det er blevet, saa maa Du med samme menneskekjærlige Begeistring som de Andre paatage Dig at gjøre Noget sværere" (SKS 7, 171f.). Climacus præciserer efterfølgende sit eget projekt og valg af stil: "Den christelige Sandhed er derved, at Alle veed den (...) Naar dette forholder sig saaledes, bliver det at kunne meddele tilsidst den Kunst at kunne fratage eller franarre" (SKS 7, 249). Hans strategi er da at fremstille det, vi mener at vide om kristendommen på en måde, der gør vores viden fremmed for os, hvilket skal muliggøre, at vi kan forholde os til kristendommen på en anden måde. Climacus' forehavende er mere specifikt at vise, at det at blive kristen ikke er nogen let opgave og det forsøger han at synliggøre ved at fremstille centrale misforståelser i hegelianernes spekulative forståelse af kristendommen. Han bestræber sig med andre ord på "at udfinde, hvor Misforstaaelsen ligger imellem Speculationen og Christendommen" (SKS 7, 219). Ifølge Climacus ligger en central del af denne misforstålse i hegelianernes sammenblanding af filosofi og kristendom, som han også finder i Martensens forsøg på at forene viden og kristen tro.

Climacus' projekt er et grænseprojekt. Han har erfaret, at man kan vide, hvad kristendom er uden at være kristen, og han er da heller ikke interesseret i hvad kristendom er, men i at blive kristen (SKS 7, 347). Han har tillige erfaret, at man ikke bare kan beslutte at blive kristen, for det kræver slet ingen beslutning, men tro. Problemet er

19. Søren Kierkegaard, Søren Kierkegaards Skrifter. K7 Kommentarbind til Afsluttende uvidenskabelig Efterskrift (København: Gads Forlag 2002), 242.

20. Hans L. Martensen, Grundrids til Moralphilosophiens System (København: C.A. Reitzel 1841), 60; citeret i SKS K7, 243.

21. Tonny Aagaard Olesen, "The Hermeneutics of Humor in the Postscripts", Søren Kierkegaard and the Word(s). Essays on Hermeneutics and Communication, red. Poul Houe \& Gordon D. Marino (København: C.A. Reitzel 2003), 215-227 (220f.). 
nu, som bl.a. Dalferth har påpeget, at Climacus har indset, at man ikke selv kan sætte troens bevægelse i gang, for i troen bliver man bevæget af Gud. ${ }^{22}$ Tro er ikke en viljesakt men snarere en akt, hvori der gives afkald på at ville, dvs. i troen hengiver eller overgiver man sig til Gud i håbet om, at for Gud er alt muligt. Jeg mener, at den manglende sans for vigtighed eller påtrængende nødvendighed (lack of sense of urgence), som Lippitt bestemte som et karaktertræk ved humoristen, udspringer af Climacus' forståelse af, at mennesket ikke kan blive kristen ved at beslutte at tro, snarere end af en egentlig tilfredsfred med øjeblikkets vilkår, sådan som det nogle steder antydes i Lippitts tekst (Lippitt 1997, 192; 2000, 60). Man kan dog indvende, at Lippitt blot gengiver Climacus' egne ord (SKS 7, 560), men dertil kan man spørge: Hvis humoristen virkelig var tilfreds med øjeblikkets vilkår og sin egen sikring i erindringens evighed, hvorfor er han da så optaget af at blive kristen, altså af at blive noget andet end det han er? Er det ikke mere plausibelt, at han også forholder sig "humoristisk" til sit eget grundvilkår?

Climacus' forholdsmåde er ikke tro, men forståelse, dvs. han prøver at forstå, hvad det vil sige at blive kristen ved at undersøge, hvad den kristne overkommer i bevægelsen fra den før-kristne til den kristne eksistensform. De såkaldte eksistenssfærer tjener til at belyse denne bevægelse. At blive kristen skal ikke forstås som et brud med enten en æstetisk, en etisk eller en ikke-kristen, religiøs eksistensform, men som et radikalt brud med dem alle (Dalferth 2005, 262f.). Climacus befinder sig i grænseområdet mellem forståelse og tro og med hensyn til troen forstår han, at der intet er at forstå. Det lyder banalt, men det er netop dette, hegelianerne ifølge Climacus misforstår. Climacus forstår desuden, at det at blive kristen er noget, der hænder mellem det berørte menneske og Gud - og ingen andre (SKS 7, 78f.). Denne erfaring afspejler sig i hans meddelelsesform, for ligesom Sokrates har Climacus indset, at maieutikken er det højeste forhold, som et menneske kan indtage overfor et andet (SKS 4, 219f.). Gud kan "aldrig blive Trediemand", som det hedder i Efterskriften - "dette er netop det Religieuses Hemmelighed” (SKS 7, 67). Nærmere bestemt hævder Climacus, at menneskets forhold til Gud er en hemmelighed. ${ }^{23}$ Som vi har set, består hemmelighedens betydning deri, at den ikke ligefrem lader sig meddele ( $S K S$ 7, 79), og Climacus bestemmer da ikke overraskende sin egen meddelelsesform som indirekte ( $S K S$ 7,

22. Ingolf U. Dalferth, "Becoming a Christian according to the Postscript. Kierkegaard's Christian Hermeneutics of Existence", Kierkegaard Studies Yearbook (2005), 242-281 (260).

23. “- Sæt En vilde meddele den Overbeviisning, at et Menneskes Guds-Forhold er en Hemmelighed" (SKS 7, 78). 
220). Men har jeg dermed ikke vist det modsatte af hvad jeg satte mig for: at der ikke er forskel på humor og ironi, da de begge er indirekte meddelelsesformer?

Jeg mener, at den hemmelighed, som Climacus peger på i Efterskriften, dvs. gudsforholdet, ikke er en hemmelighed af samme type, som de hemmeligheder Eremita pegede på i Enten - Eller. Her omfattede hemmelighederne både det æstetiske, det etiske og det religiøse og tesen var, at disse hemmeligheder (kun) lod sig meddele indirekte. Det er nu min påstand, at Climacus har erfaret, at det kristne gudsforhold end ikke kan meddeles indirekte (altså via ironi), og at forskellen mellem de to typer af hemmeligheder kommer til udtryk som en forskel mellem to meddelelsesformer: ironi og humor. For at opspore denne forskel udlægger jeg nu Climacus' sandhedsopfattelse som en kritik af Hegels sandhedsteori og dermed det filosofiske system. For bedre at forstå denne kritik må det fastholdes, at Climacus' ærinde er at afhjælpe den ifølge ham problematiske sammenblanding af spekulativ filosofi og kristendom, dvs. hans kritik retter sig hovedsageligt mod hegelianernes forståelse af kristendommens sandhed: at Guden blev menneske - at det evige blev til i tiden.

\section{Ironi, humor og opgøret med det filosofiske system}

I Efterskriften formulerer Climacus sin sandhedsopfattelse på følgende måde: “- Sæt En vilde meddele, at ikke Sandheden er Sandheden, men Veien er Sandhed: at Sandheden kun er i Vordelsen, i Tilegnelsens Proces, at der altsaa intet Resultat er" (SKS 7, 78). Ved første øjekast kan denne sandhedsopfattelse læses som en kritik af korrespondensteorien for sandhed, hvor sandhed tænkes som det rette forhold mellem et udsagn og det, der udsiges noget om. Det rette forhold er præcis det forhold, hvor udsagnet stemmer overens med det, hvorom det udsiges. ${ }^{24}$ I modsætning til korrespondensteorien, der netop tænker sandhed som resultat, indvender Climacus, at der "intet Resultat er", men at "Veien er Sandhed". Når han betoner vejen eller processen frem for processens resultat, placerer han tilsyneladende sin sandhedsopfattelse i opposition til korrespondensteorien, men jeg mener dog snarere, at den skal forstås som betingelsen for korrespondensteorien. Når Climacus hævder, at "Sandheden kun er i Vordelsen, i Tilegnelsens Proces", så betyder det, at sandheden først bli-

24. Korrespondensteorien for sandhed får sin klassiske formulering "veritas est adaequatio rei et intellectus" hos Aquinas (Summa Theologiae, Q.XVI A.1), men teorien føres ofte tilbage til Aristoteles' bestemmelse af sandhed (Metafysikken, 1011 b 25-28). 
ver sandhed, når den tilegnes. Når sandhed tænkes som adaequatio, som resultatet af en proces, er der en tendens til at overse, at resultatet først blev resultat på baggrund af en forudgående proces. For Climacus, der ikke er kristen, men som er optaget af at blive det, er processen selvsagt det væsentlige.

Ved nærmere eftersyn kan Climacus' sandhedsopfattelse dog også læses som en kritik af Hegels sandhedsteori (se f.eks. SKS 7, 173228). For at vise dette, skitserer jeg først grundtrækkene af Hegels sandhedsteori. Hegel bestemmer som bekendt sandhed i subjektiv, objektiv og absolut betydning. Han bestemmer sandhed i subjektiv betydning som en forestillings overensstemmelse med sin genstand, og sandhed i objektiv betydning som sagens overensstemmelse med sig selv. ${ }^{25}$ Sandhed i absolut betydning bestemmer han i forordet til Phänomenologie des Geistes på følgende måde: "Das Wahre ist das Ganze. Das Ganze aber ist nur das durch seine Entwicklung sich vollendende Wesen. Es ist von dem Absoluten zu sagen, daß es wesentlich Resultat, daß es erst am Ende das ist, was es in Wahrheit ist". Hegels bestemmelse af sandhed i subjektiv og objektiv betydning ligner korrespondensteorien for sandhed, men hans sandhedsteori kan ikke reduceres til denne, da han også bestemmer sandhed som helhed. Climacus' kritik af Hegels sandhedsteori er derfor dobbelt. For det første kritiserer han, at Hegel med sin bestemmelse af sandhed i subjektiv og objektiv betydning inkorporerer korrespondensteorien for sandhed i sin sandhedsteori og dermed i det filosofiske system. Hos f.eks. Martensen kan vi se, at kristendom betragtes som en form for objektiv viden $(1850,14)$ og hans spekulative teologi forpligter sig på korrespondensteorien for sandhed $(1850,27)$. For det andet kritiserer Climacus Hegels bestemmelse af sandhed i absolut betydning, altså sandhed som helhed eller proces. Denne kritik er tilsyneladende paradoksal, for Climacus bestemmer også selv sandhed som proces. Hvad er da forskellen mellem Climacus' sandhedsopfattelse og Hegels sandhedsteori? Det afgørende i Climacus' kritik synes at være, at Hegels bestemmelse af sandhed som helhed forudsætter bestemmelsen af sandhed som adaequatio. Når Hegel hævder, at det absolutte væsentligt er resultat, og at det først ved afslutningen er det, som det egentlig er, så betyder det for Climacus, at Hegel tager udgangspunkt i sandheden som resultat og derfra viser vejen til sandhed. Dermed bliver sandhedsprocessen transparent. Hegels bestemmelse af sandhed som helhed får således spændingen mellem sandhed som proces og sandhed som resultat til at forsvinde. Det der mistes 
når den spænding forsvinder er den konkrete subjektivitet, dvs. det eksisterende menneske der ikke allerede besidder sandheden, men som søger den. Men sandheden - og det vil for Climacus her især sige den kristne sandhed - er ikke givet for mennesket, men stillet for det som en gåde. Når spændingen mellem sandhed som proces og sandhed som resultat forsvinder i Hegels filosofi, forsvinder også modsætningen mellem det indre og det ydre. Der er ingen hemmeligheder i Hegels filosofi.

På den baggrund mener jeg, at vi kan sondre mellem to stilistiske aspekter i Climacus' opgør med Hegels filosofiske system. Det ene aspekt udgøres af den indirekte meddelelse, dvs. ironien. Den indirekte meddelelse kan læses som et opgør med den objektive tænkning; den tænkning der tænker sandhed som adaequatio. Den objektive tænkning har ingen hemmeligheder, som Climacus skriver (SKS 7, 79). Derimod er den indirekte meddelelse hemmelighedsfuld, da det der meddeles ikke kan meddeles direkte. Med andre ord, Climacus anvender Sokrates mod Hegel. Dersom Climacus' projekt var det sokratiske og blot et opgør med den objektive tænkning, så var ironien nok. Men Climacus' projekt er et andet og han har erfaret, at ironien ikke er tilstrækkelig til at udgøre et opgør med hele det filosofiske system. Sokrates løser kun halvdelen af problemet og Climacus må derfor gå hinsides Sokrates. Allerede i Smulerne bestemte han sit forehavende som et projekt, der "gaaer udisputeerligt videre end det Socratiske" (SKS 4, 306). Skønt det ikke entydigt lader sig afgøre i hvilken forstand Climacus' projekt "gaaer videre" end det sokratiske, ${ }^{26}$ så er det i det mindste klart, at den sokratiske indsigt (dvs. at den erkendende er eksisterende) er indeholdt $\mathrm{i}$, ja tilmed accentueret og radikaliseret i Climacus' projekt (SKS 7, 187ff.). Når Climacus beskriver den proces det er at blive kristen, så befinder han sig i grænseområdet mellem det sokratiske og det kristelige, og her er ironien ikke nok.

Det andet stilistiske aspekt ved systemopgøret udgøres af humoren. Humoren indeholder ironien, men den kan ikke reduceres til ironi, $\mathrm{da}$ den indeholder en anerkendelse af ironiens grænse. Forskellen mellem ironi og humor står i forbindelse med forskellen mellem Sokrates og Kristus - en forskel som i Kierkegaards samtid blev diskuteret som et teologisk problem ${ }^{27}$. Han bestemte allerede denne forskel i sin afhandlings første tese "Similitudo Christum inter et Socratem in dissimilitudine præcipue est posita" (SKS 1, 65), dvs. ligheden mel-

26. Se f.eks. Arne Grøn, “Sokrates og Smulerne”, Filosofiske Studier 15 (1995), 97107.

27. I Om Begrebet Ironi henviser han til F.C. Baurs Das Christliche des Platonismus oder Sokrates und Christus fra 1837 (SKS 1, 75). 
lem Sokrates og Kristus består først og fremmest i ulighed. F.eks. kan Kristus ligefremt sige: "Jeg er sandheden" (Joh 14, 6). Det kan Sokrates ikke og derfor har han brug for negativiteten. Ironien mangler referencen til det direkte og derfor kan Climacus ikke (kun) anvende Sokrates' metode. I den forstand bliver forskellen mellem Sokrates og Kristus hos Climacus til en forskel mellem to meddelelsesformer: ironi og humor. For at se hvordan humoren adskiller sig fra ironien, kan vi betragte Climacus' meddelelse om Gud-Mennesket, dvs. meddelelsen om at Kristus i én og samme person er Gud og menneske ${ }^{28}$. Der er tale om et grænsebegreb: Gud-Mennesket er et paradoks for fornuften, men ikke for troen. Jeg mener, at meddelelsen om GudMennesket kan læses som et opgør med den rene tænken i Hegels filosofi, altså den tænkning der tænker sandhed i absolut betydning. Den rene tænken tænker sig selv, dvs. sin egen proces, og der er derfor ikke noget utænkt i den rene tænken. I Hegels filosofi er den absolutte viden en viden uden hemmeligheder - den kan ikke rumme radikale paradokser. Med meddelelsen om Gud-Mennesket refererer Climacus til den tanke, som den rene tænken ikke kan forholde sig til på en direkte måde. Gud-Mennesket kan ikke integreres i tankens helhed - i den helhed der er sandheden for Hegel. Climacus prøver således at vise, at viden også i sin højeste form indeholder noget, der ikke kan tænkes og at kristendommens sandhed (at Guden blev menneske) dermed ikke kan integreres i det filosofiske system. Om GudMennesket kan vi intet forstå andet end forståelsens grænse. Troen på Gud-Mennesket er en tro på det absolutte paradoks, men troen er også selv paradoksal: ikke kun fordi den ikke kan forklares eller retfærdiggøres forstandsmæssigt, men mere afgørende fordi troen er den subjektive tilegnelse og gentagelse af det absolutte paradoks (Dalferth 2005, 161).

De stilistiske aspekter ved opgøret med det filosofiske system udgøres henholdsvis af den indirekte meddelelse (ironien) og meddelelsen om Gud-Mennesket (humoren). Ironien omfatter både meddelelser med et æstetisk, etisk eller ikke-kristent, religiøst indhold. Humoren indeholder ironien, dvs. ironiens indirekte dimension, men til forskel fra ironien rummer humoren også en direkte dimension. Det er i det mindste min påstand. Climacus udtrykker det ikke selv på denne måde, men idet han bestemmer det at være kristen i subjektiv betydning, skriver han: "Det at være Christen bestemmes ikke ved Christendommens Hvad, men ved den Christnes Hvorledes. Dette Hvorledes kan kun passe til Eet, til det absolute Paradox" (SKS 7, 554).

28. I Smulerne (men også nogle steder i Efterskriften) anvender Climacus formuleringen "Guden i Tiden" (se f.eks. SKS 4, 306). 
Med andre ord, selvom det at være kristen først og fremmest bestemmes ved den måde, hvorpå den kristne forholder sig til Gud, så henviser denne forholdsmåde dog uundgåeligt til ét bestemt indhold: Kristus. Humoren har derfor ikke kun en indirekte dimension, men også en direkte dimension.

På den baggrund mener jeg, at der er en sammenhæng mellem ironi og humor forstået som meddelelsesformer og de meddelelsesformer, som Kierkegaard i forelæsningsudkastene kalder "den ethiske Meddelelse" og "den ethisk-religieuse Meddelelse" (Pap. VIII 2 B 7989). Her hævder han, at den etiske meddelelse er "indirecte" og at den etisk-religiøse meddelelse er "directe-indirecte" (Pap. VIII 2 B 85,27). Den etisk-religiøse meddelelse, humoren, har en direkte dimension. Den må begynde som en meddelelse af viden, fordi mennesket til at begynde med ikke er vidende om det religiøse. Meddelelsen om Gud-Mennesket er først en ligefrem meddelelse om det historiske forhold, at Kristus har eksisteret som menneske. Forskellen mellem den etiske og den etisk-religiøse meddelelse, mellem ironi og humor, afspejles i forskellen mellem den sokratiske og den kristelige opfattelse af tilegnelse. Sokrates bestemte tilegnelse som erindring (Menon, 81d). I Smulerne udlægger Climacus dette sådan, "at den Uvidende blot behøver at mindes, for ved sig selv at besinde sig paa, hvad han veed. Sandheden bringes saaledes ikke ind i ham, men var i ham" (SKS 4, 218). Mennesket har sandheden i sig, skønt det ikke altid har blik for det sande. Når Climacus går videre end Sokrates, ændres opfattelsen af tilegnelse. Kristeligt forstået er tilegnelse ikke erindring. I syndsbevidstheden har mennesket ikke sandheden i sig. Mennesket er sat uden for sandheden: erindringens bagdør er for evigt lukket (SKS 7, 191). Climacus udtrykker det sådan, at sokratisk set var subjektiviteten sandheden, men efter Kristus må mennesket erfare, at dets vilkår er forandret: at subjektiviteten nu til at begynde med er usandheden (SKS 7, 190).

Den etisk-religiøse meddelelse er altså først en meddelelse af en viden, som mennesket ikke allerede besad. Meddelelsen om Gud-Mennesket, humoren, indeholder derfor en direkte dimension, selvom meddelelsen væsentligt er indirekte. Climacus kan redegøre for den etisk-religiøse meddelelses indirekte dimension, men da han ikke er kristen, kan han ikke redegøre for dens direkte dimension. Der møder han sin grænse og det forstår han, dvs. han forstår at i forhold til det absolutte paradoks er der intet at forstå. Derfor er humor, som han hævder, "altid Tilbagekaldelse" (SKS 7, 547). Med andre ord, humoren fornemmer ikke kun ironiens grænse, men også sin egen grænse. Det fremgik allerede, idet Climacus i Smulerne betegnede sit forehavende som et "Tanke-Projekt" $(S K S 4,218)$, dvs. han fremsæt- 
ter et projekt om det, som intet menneske ifølge dette projekt kan tænke sig frem til: at blive kristen. Kierk egaard får derfor brug for andre pseudonymer for at gå hinsides Climacus: Anti-Climacus. 